\title{
Human Milk Cell Migration and Production of Monocyte Chemotactic Factor: Lack of Activity
}

\author{
CATHERINE S. HAWES AND W. R. JONES \\ Department of Obstetrics and Gynaecology, Flinders Medical Centre, Bedford Park, South Australia, 5042
}

\begin{abstract}
The lymphocytes of human breast milk have been previously shown to be immunologically competent while the monocytes have been described as actively motile in some reports but not in another. Cells were separated from milk samples collected by lactating women 2 to 9 days postpartum. Milk cell migration and production of the lymphokine, monocyte chemotactic factor, by milk cells were assayed using membrane filters. Milk cells were poorly motile although prior culturing improved their migratory ability. Cell-free milk was chemotactic for blood monocytes. Chemotactic factor production was detected in only two of 16 phytohemagglutinin-stimulated milk cell cultures. (Pediatr Res 19: 996-999, 1985)
\end{abstract}

\section{Abbreviations}

PHA, phytohemagglutinin

HBSS, Hanks' balanced salt solution

MCF, monocyte chemotactic factor

Human milk contains a large number of immunologically active components (1). Soluble factors include secretory component, immunoglobulins, and complement. Cells identified in colostrum and milk are predominantly mononuclear phagocytes with small proportions of lymphocytes and neutrophils. Functional studies of these cells were first described by Smith and Goldman (2). They found that the mononuclear phagocytes, comprising about $80 \%$ of the milk leucocytes, ranged in size up to $30 \mu \mathrm{m}$ diameter, with a prominent nucleolus and cytoplasm containing many fat globules. They adhered to and spread on glass, extending a cytoplasmic veil, and were described as exhibiting ameboid movements. Adherence and spreading on glass also have been described by Lascelles et al. (3), Mohr et al. (4) and Pitt (5). From these descriptions and the work of Mohr et al. (4), who also studied capillary tube migration, it has been assumed that milk mononuclear phagocytes are actively motile. Pitt (6), however, found that they were not motile in capillary tubes or under agarose. Milk cells are actively phagocytic and microbicidal $(2-4,7,8)$. Milk mononuclear cells react with the commercially available monoclonal antibodies $\mathrm{OKMI}$ and $\mathrm{OKIa}$ and present antigens to T-cell blasts (9).

The lymphocytes, which comprise between 5 and $35 \%$ of the total milk cells (10-13) also exhibit in vitro activity. They proliferate in response to stimulation by PHA, antigens, and allogeneic cells $(2,10,11,14-16)$ and produce the lymphokines, migration inhibition factor (4), interferon (17-19), and MCF (19).

It has been postulated that these cellular activities are of benefit to the breast-fed neonate. Thus, the described transmission of

Received September 24, 1984; accepted May 16, 1985.

Reprint requests Dr. C. S. Hawes, Department of Obstetrics and Gynaecology, Flinders Medical Centre, Bedford Park, South Australia, 5042. cellular immunity to purified protein derivative via breast milk may possibly be mediated by lymphokine transfer $(20,21)$.

In view of the contrasting findings regarding milk cell motility and the indication that lymphokine is produced by milk cells, we decided to investigate milk cell migration and production of monocyte chemotactic factor using Millipore membrane filters to assay migration.

\section{METHODS}

Samples of breast milk were collected from healthy lactating women 2-9 days after delivery. The milk was defatted by diluting 3 fold in phosphate-buffered saline and centrifuging $400 \times g / 15$ $\min$. The fat layer was aspirated off, and the tubes were inverted and drained for a few minutes to remove more fat from the walls of the tubes. The cell buttons were washed three times in phosphate-buffered saline.

Cell migration was assayed using methods previously described (22). Cells were resuspended at $5 \times 10^{6} \mathrm{cells} / \mathrm{ml}$ in HBSS (Commonwealth Serum Laboratories, Melbourne, Australia), pH 7.4, containing $2 \%$ bovine serum albumin and dispensed in $0.1 \mathrm{ml}$ volumes into chemotactic chambers. These were constructed by sawing off tuberculin syringes to $18 \mathrm{~mm}$ length and attaching 8 $\mu \mathrm{m}$ pore size cellulose ester filters (SCWP, Millipore Corp., Bedford, MA) to the bottom of each chamber using a nontoxic adhesive. Each chamber was suspended in a $2 \mathrm{ml}$ autoanalyzer cup containing $0.4 \mathrm{ml}$ of test solution and then incubated for 2.5 $\mathrm{h}$ in a humidified atmosphere of $5 \% \mathrm{CO}_{2}$ in air. All assays were performed in triplicate.

Migration was quantified after fixing and staining the filters by measurement of the leading front of migrating cells, taken as the furthest distance through the filter with at least three cells in focus. Each filter was read in quadruplicate and the migration in $\mu \mathrm{m}$ was expressed as the mean of the determinations made on each of the three filters.

As will be described later, it was not practicable to use the leading front method to detect milk cell migration as so few cells entered the filters. Hence to assess migration, cells in focus were counted at successive depths within the filters. Ten fields $(\times 500)$ were counted at each level in each of the three filters and the mean number of migrating cells determined.

Polycarbonate membranes (Nuclepore, N500 Pleasanton, CA) ( $5 \mu \mathrm{m}$ pore size) were also used for the detection of milk and blood cell migration. These were attached to chemotactic chambers in the same manner as the cellulose ester filters. Incubation was for $90 \mathrm{~min}$. Migration was assessed by counting cells which had migrated through the filter and reached the bottom surface. Ten fields $(\times 1250)$ were counted on each of triplicate filters.

To assess random migration, HBSS was added to the autoanalyzer cups. To assess stimulated migration, $5 \mathrm{mg} / \mathrm{ml}$ casein in HBSS was used as a chemotactic stimulus. To detect MCF, control and PHA-stimulated cell culture supernatants were placed below the filters.

Cells were cultured for MCF production as previously de- 
scribed (23). Washed Ficoll-Hypaque separated peripheral blood mononuclear cells or milk cells prepared as described above were resuspended at $3 \times 10^{6} \mathrm{cells} / \mathrm{ml}$ in medium 199 containing $0.5 \%$ pooled male human serum and antibiotics (penicillin 50 units/ $\mathrm{ml}$ and streptomycin $50 \mu \mathrm{g} / \mathrm{ml}$ ) for culture. Each $1 \mathrm{ml}$ culture was dispensed as $5 \times 0.2 \mathrm{ml}$ aliquots in microtiter trays and incubated for $48 \mathrm{~h}$ at $37^{\circ} \mathrm{C}$ in a humidified $5 \% \mathrm{CO}_{2}$ in air atmosphere. Control cultures had no addition; stimulated cultures contained $1 \mu \mathrm{g} / \mathrm{ml}$ PHA (purified, Wellcome Laboratories, Kent, England). The supernatants were harvested by gentle aspiration and each group of five pooled before storage at $4^{\circ} \mathrm{C}$.

Monocytes harvested by Ficoll-Hypaque separation from peripheral blood were used to detect MCF in the supernatants (23). The migration of monocytes toward control and stimulated culture supernatants was determined by the leading front method and the significance of any difference between the migration obtained toward each pair of control and stimulated supernatants was assessed by the Mann-Whitney U test. PHA-stimulated culture supernatants were considered positive if they promoted significantly enhanced monocyte migration $(p<0.05)$ as compared to control supernatants.

When testing milk cell culture supernatants, pretested positive supernatants produced by PHA-stimulation of blood mononuclear cell cultures were also run concurrently as a control. These cells were obtained either from peripheral blood of healthy adult volunteers or from cord blood obtained at delivery. Cord blood mononuclear cells are active in both production and detection of MCF (24).

\section{RESULTS}

Milk cell preparation. The yield of milk cells varied widely $\left(0.11\right.$ to $4 \times 10^{6}$ cells per ml milk from 40 samples collected from 37 subjects). Ficoll-Hypaque centrifugation proved unsatisfactory due to large cell losses. Although this step was omitted, polymorphonuclear cell migration into the filters was detected in only two of 15 assays of samples from different subjects.

Milk cell migration in Millipore filters. Determination of cell migration by the leading front method is based on measuring the distance traveled into the filter by a "leading front" of three cells in focus. This was found not to be practicable in the milk cell experiments since so few cells migrated into the filter that very few microscopic fields contained three cells. To enable a comparison between milk and blood cells to be made, the number of cells migrating into the filters was compared by counting cells in focus at successive depths within the filters. Ten fields were counted at each level in each of three filters.

The migration of milk cells collected from five subjects on days $4,5,6,7$, and 9 postpartum is compared with cord blood cell migration in Figures 1 (HBSS) and 2 (casein). The lack of motility of milk cells can be clearly seen. In HBSS, an average total of 52 milk cells migrated into the filter compared with 448 cord blood cells and in response to casein 52 milk cells compared with 1182 cord blood cells migrated into the filter.

By the leading front method, migration of the milk cells was less than $5 \mu \mathrm{m}$ in the presence of both HBSS and casein whereas the migration of the cord blood cells was $31 \mu \mathrm{m}$ in HBSS and 85 $\mu \mathrm{m}$ in casein.

Migration of milk cells after culture. To investigate whether components of milk were inhibiting milk cell migration despite washing, milk cells were prepared as above and cultured at $1 \times$ $10^{6}$ cells $/ \mathrm{ml}$ in medium 199 for $24 \mathrm{~h}$. The cells were harvested by aspiration and scraping, washed twice, and added to chemotactic chambers for migration assay. Table 1 shows that three of four milk cell preparations had enhanced random migration (determined in the presence of HBSS) after culturing.

The cultured samples also had enhanced chemotactic migration when casein was used as a chemotactic stimulus. The number of cells migrating was greatly increased, enabling measurement of migration by the leading front method to be made

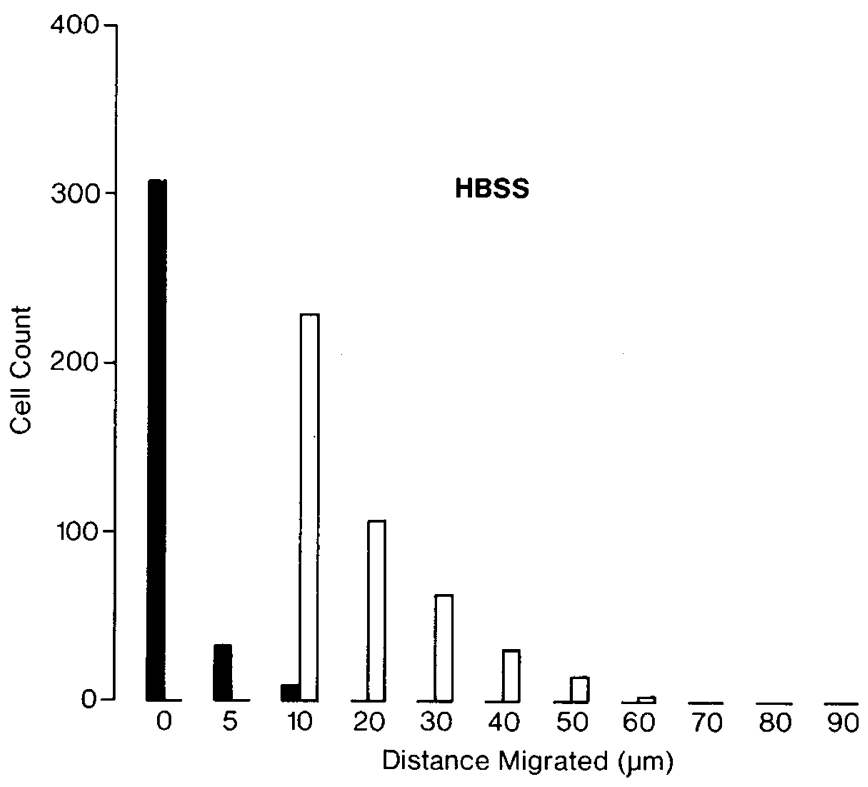

Fig. 1. Cell migration into Millipore filters in the presence of HBSS. The total migrating cell count in ten microscopic fields at each depth within triplicate filters is indicated. Solid bar, milk cells (mean of five samples from five subjects). Open bar, cord blood mononuclear cells (one sample).

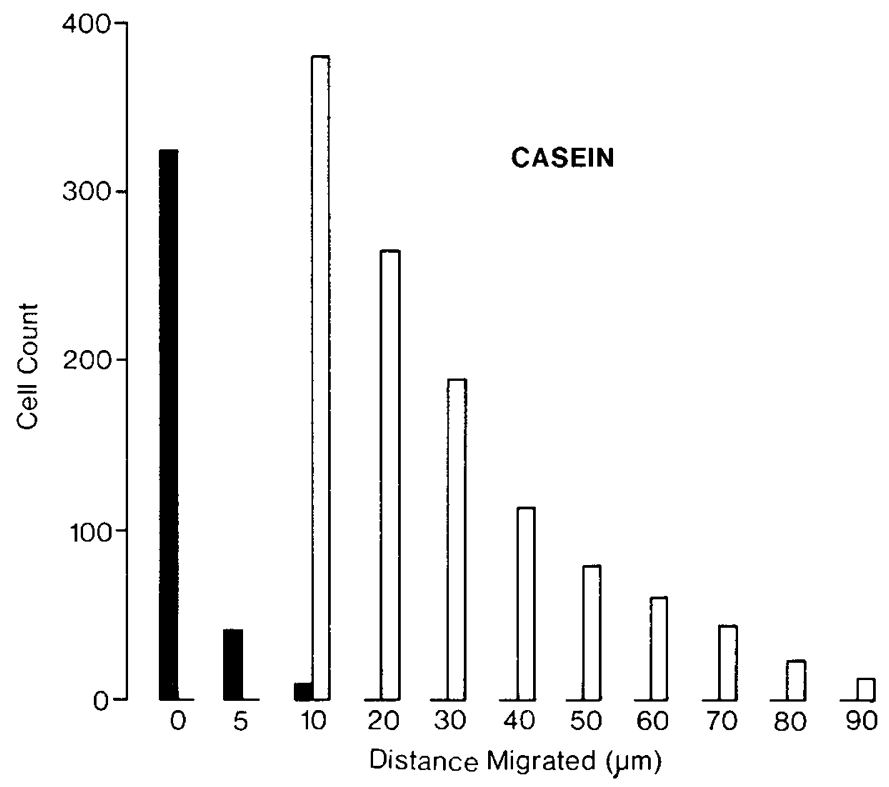

Fig. 2. Casein-stimulated cell migration into Millipore filters. Casein $(5 \mathrm{mg} / \mathrm{ml}$ in HBSS) was placed below the filters. Migrating cells were counted in ten microscopic fields within each of three filters at the depths indicated in $\mu \mathrm{m}$. Solid bar, milk cells (mean of five samples from five subjects). Open bar, cord blood mononuclear cells (one sample).

(samples 1 and 2). When the chemotactic peptide, f-Met-leu-phe, was used, however, no enhancement was seen (samples 3 and 4, Table 1).

Milk cell migration through polycarbonate membranes. Polycarbonate membranes ( $5 \mu \mathrm{m}$ pore size) have been commonly used in assays of human monocyte migration $(25,26)$. Migration of milk and cord blood cell preparations through these $10-\mu \mathrm{m}$ thick filters was compared. Migration is assessed by counting cells which have migrated through the filter and reached the lower surface after $90 \mathrm{~min}$ incubation. Ten oil immersion fields were counted in each of triplicate filters. Random migration of milk cells was extremely low $(0.8 \pm 0.4$ cells in 10 fields, mean 
Table 1. Milk cell migration after culture

\begin{tabular}{|c|c|c|c|c|}
\hline \multirow[b]{2}{*}{$\begin{array}{c}\text { Sample } \\
\text { no. }\end{array}$} & \multicolumn{2}{|c|}{$\begin{array}{l}\text { HBSS (average cell } \\
\text { count on } 10 \\
\text { fields*) }\end{array}$} & \multicolumn{2}{|c|}{$\begin{array}{l}\text { Casein (migration } \\
\text { distance in } \mu \mathrm{m} \dagger \text { ) }\end{array}$} \\
\hline & $\begin{array}{l}\text { Before } \\
\text { culture }\end{array}$ & $\begin{array}{c}\text { After } \\
\text { culture }\end{array}$ & $\begin{array}{l}\text { Before } \\
\text { culture }\end{array}$ & $\begin{array}{c}\text { After } \\
\text { culture }\end{array}$ \\
\hline $1^{*}$ & 20 & 96 & nd & $37 \mu \mathrm{m}$ \\
\hline \multirow[t]{2}{*}{2} & 46 & 521 & $<5 \mu \mathrm{m}$ & $19 \mu \mathrm{m}$ \\
\hline & & & \multicolumn{2}{|c|}{$\begin{array}{l}\text { Chemotactic } \\
\text { peptide f-Met-leu- } \\
\text { phe }\left(10^{-8} \mathrm{M}\right) \\
\text { (average cell count } \\
\text { in } 10 \text { fields) }\end{array}$} \\
\hline 3 & 10 & 10 & 13 & 11 \\
\hline 4 & 10 & 30 & 24 & 6 \\
\hline
\end{tabular}

* Cells were counted in triplicate filters for each determination. In sample 1 , counting was at a depth of $10 \mu \mathrm{m}$ since there were too many cells (>100 per field) at $5 \mu \mathrm{m}$. In the remainder, cells were counted at 5 $\mu \mathrm{m}$.

† Enhanced migration by the cultured cell samples in the presence of casein enabled leading front determinations of migration.

Table 2. Effect of milk on blood monocyte migration*

\begin{tabular}{ccccc}
\hline $\begin{array}{c}\text { Concentration } \\
\text { of milk above } \\
\text { filter (\%) }\end{array}$ & \multicolumn{4}{c}{$\begin{array}{c}\text { Concentration of milk below } \\
\text { filter (\%) }\end{array}$} \\
\cline { 2 - 5 } & 0 & 1 & 10 & 20 \\
\hline 0 & 38 & 52 & 70 & 63 \\
1 & 40 & 45 & 52 & 55 \\
10 & 47 & 49 & 46 & 52 \\
20 & 51 & 48 & 48 & 51 \\
\hline
\end{tabular}

* The milk sample used was collected on day 2 and diluted in HBSS. Monocytes were separated from cord blood. Monocyte migration (in $\mu \mathrm{m})$ is expressed as the mean of four determinations in each of three filters.

$\pm \mathrm{SD} ; n=4)$ compared to cord blood monocytes $(11 \pm 4 ; n=$ 2 ). When casein was present, milk cell migration was again very poor $(2.8 \pm 4.6 ; n=4)$ compared to cord monocytes $(217 \pm 144$; $n=2$ ).

Effect of milk on blood monocyte migration. To test whether milk inhibits cell migration, a possible explanation for the lack of milk cell migratory activity, a checkerboard assay was set up in which a range of concentrations of defatted, cell free milk was used above and below the Millipore filters with a monocyte preparation from cord blood. Migration was determined as shown in Table 2. When equal concentrations of milk were present on each side of the filter, monocyte migration, shown in the diagonal from upper left to lower right, increased slightly over the concentration range 1 to $20 \%$. This increase in migration, however, was not significant by the Mann Whitney $U$ test $(p>0.05)$, thus indicating little or no chemokinetic activity. Monocyte migration obtained in response to a positive gradient, represented by those results. on the right of the diagonal, was slightly, but significantly increased $(p<0.05$, Mann Whitney $\mathrm{U}$ test) over the migration in the presence of a negative gradient, represented by the results on the left of the diagonal. This indicates that milk exerts a chemotactic, but little or no chemokinetic, effect on blood monocytes.

Production of MCF by milk cells. Milk cells separated from 10 samples collected from nine subjects on days $2,4,5,6,7$, and 8 postpartum were cultured with PHA. The culture supernatants were tested for MCF using blood monocytes. Only one of the 10 cultures was positive. Half of these cultures were set up in duplicate and tested on separate occasions with different indica- tor monocytes but remained negative. Additional milk cells collected on days 2, 4, 6, and 8 from another four women were cultured for $72 \mathrm{~h}$. One of six was positive.

\section{DISCUSSION}

Human milk cells displayed poor migratory activity and production of PHA-induced monocyte chemotactic factor.

The poor migratory ability found in two types of filter assays is in agreement with results using the capillary tube and agarose migration assays briefly reported by Pitt (6). The motility previously attributed to milk mononuclear cells was based on visual observations during incubation on glass slides (2) in which cell spreading may have been equated with locomotion. In fact, spreading of blood monocytes is accompanied by a loss of locomotion (27). In another study, the large colostral cells were described as displaying "very occasional, extremely sluggish movement" (3).

Not only did the milk cells exhibit a very low random mobility into the filters in the absence of any stimulant but no increase in migration was seen when the chemoattractants casein and the peptide f-Met-leu-phe were used. Nor was there any stimulation of milk cell migration in the presence of serum or monocyte chemotactic factor (results not shown). It is possible that the milk cells become deactivated by the continual presence of chemoattractants in milk and are not able to respond even after their removal by washing. After $24 \mathrm{~h}$ in culture, random and caseinstimulated migration was noticeably increased, implying that deactivation may be a contributing factor to the poor mobility of freshly isolated cells. Since migration is observed after culture, it seems less likely that the poor migration of milk cells is simply due to the absence of motile cells. The chemotactic property of milk was confirmed by the checkerboard experiment and is presumably due to its casein content, a known chemotactic factor for human monocytes (28). The migratory activity of the milk cells on polycarbonate filters may be compared with published results for human alveolar macrophages (29). Average cell counts obtained were 5.7 and 16.9 cells undergoing random and stimulated migration, respectively ( 20 oil fields were counted per filter). Thus, migratory ability of alveolar cells was much lower than that of blood monocytes but that of milk cells was even less.

In contrast to the low activity of milk macrophages, milk neutrophils are capable of both random and stimulated migration (30). Milk neutrophil migration was not extensively assessed in this study since only two milk samples were found to contain neutrophils. In these samples migration was less than that of blood neutrophils, in agreement with Khan et al. (30).

Monocyte chemotactic factor was detected in only two of 16 PHA-stimulated milk cell cultures. By comparison, MCF was detected in $70 \%$ of PHA-stimulated peripheral blood mononuclear cell cultures using the leading front method to determine migration of indicator monocytes (23). In contrast to the present study, nine of 11 milk lymphocyte cultures produced MCF using polycarbonate filters to detect migration (19). The low incidence of MCF detection in unseparated milk cell cultures may have been due to the lower proportion of lymphocytes present. Peripheral blood mononuclear cell preparations contain $70-80 \%$ lymphocytes while milk cell preparations contain $5-35 \%(10$ 13). However, MCF could still be detected in blood mononuclear cell preparations diluted 30-fold (23). The apparent lack of activity of the milk cell cultures, when MCF was assayed using Millipore membranes, may be due to a relative hyporesponsiveness of milk cells compared to blood lymphocytes which was not detected by the polycarbonate filter assay. Hyporesponsiveness of milk lymphocytes to mitogen stimulation also has been seen in transformation assays $(10,15,16)$.

These studies indicate that milk cells have both an impaired migratory activity and ability to produce the lymphokine, mon- 
ocyte chemotactic factor, in comparison to blood mononuclear cells.

\section{REFERENCES}

1. Ogra SS, Ogra PL 1979 Components of immunologic reactivity in human colostrum and milk. In: Ogra PL, Dayton DH (eds) Immunology of Breast Milk. Raven Press, New York, pp 185-195

2. Smith CW, Goldman AS 1968 The cells of human colostrum. I. In vitro studies of morphology and function. Pediatr Res 2:103-109

3. Lascelles AK, Gurner BW, Coombs RR 1969 Some properties of human colostral cells. Aust J Biol Med Sci 47:349-360

4. Mohr JA, Leu R, Mabry W 1970 Colostral leukocytes. J Surg Oncol 2:163167

5. Pitt J 1979 The milk mononuclear phagocyte. Pediatr 64(suppl):745-749

6. Pitt J 1978 Characterisation of the milk mononuclear phagocyte. J Reticuloendothel Soc 23:44i(abstr)

7. Pitt J, Barlow B, Heird WC 1977 Protection against experimental necrotizing enterocolitis by maternal milk. I. Role of milk leukocytes. Pediatr Res 11:906-909

8. Blau H, Passwell JH, Levanon M, Davidson J, Kohen F, Ramot B 1983 Studies on human milk macrophages: effect of activation on phagocytosis and secretion of prostaglandin E2 and lysozyme. Pediatr Res 17:241-245

9. Mori M, Hayward AR 1982 Phenotype and function of human milk monocytes as antigen presenting cells. Clin Immunol Immunopathol 23:94-99

10. Diaz-Jouanen EP, Williams RC 1974 T and B lymphocytes in human colostrum. Clin Immunol Immunopathol 3:248-255

11. Ogra SS, Ogra PL 1978 Immunologic aspects of human colostrum and milk. II. Characteristics of lymphocyte reactivity and distribution of E-rosette forming cells at different times after the onset of lactation. J Pediatr 92:550555

12. Crago S, Prince SJ, Pretlow TG, McGhee JR, Mestecky J 1979 Human colostral cells: I Separation and characterization. Clin Exp Immunol 38:585-597

13. Ho FCS, Wong RLC, Lawton JWM 1979 Human colostral and breast milk cells: a light and electron microscope study. Acta Paediatr Scand 68:389396

14. Losonsky GA, Fishaut JM, Strussenberg J, Ogra PL 1982 Effect of immunization against rubella on lactation products. I. Development and characterization of specific immunologic reactivity in breast milk. J Infect Dis 145:654-660

15. Parmely MJ, Beer AE, Billingham RE 1976 In vitro studies on the T-lympho- cyte population of human milk. J Exp Med 144:358-370

16. Ruben FL, Holzman IR, Fireman P 1982 Responses of lymphocytes from human colostrum or milk to influenza antigens. Am $\mathrm{J}$ Obstet Gynecol 143:518-522

17. Emodi G, Just M 1974 Interferon production by lymphocytes in human milk. Scand J Immunol 3:157-160

18. Lawton JWM, Shortridge KF, Wong RLC, Ng MH 1979 Interferon synthesis by human colostral leukocytes. Arch Dis Child 54:127-130

19. Keller MA, Kidd RM, Bryson YJ, Turner JL, Carter J 1981 Lymphokine production by human milk lymphocytes. Infect Immun 32:632-636

20. Mohr JA 1973 The possible induction and/or acquisition of cellular hypersensitivity associated with ingestion of colostrum. J Pediatr 82:1062-1064

21. Ogra SS, Weintraub D, Ogra PL 1977 Immunologic aspects of human colostrum and milk. III. Fate and absorption of cellular and soluble components in the gastrointestinal tract of the newborn. J Immunol 119:245-248

22. Hawes CS, Kemp AS, Jones WR 1979 Random monocyte migration: an in vitro correlation with the delayed hypersensitivity skin reaction. Clin Exp Immunol 37:567-571

23. Hawes CS, Kemp AS, Jones WR 1980 Detection of a truly chemotactic lymphokine for human monocytes using Millipore membranes. J Clin Lab Immunol 3:71-75

24. Hawes CS, Kemp AS, Jones WR 1980 In vitro parameters of cell-mediated immunity in the human neonate. Clin Immunol Immunopathol 17:530536

25. Horwitz DA, Garrett MA 1971 Use of leukocyte chemotaxis in vitro to assay mediators generated by immune reactions. J Immunol 106:649-655

26. Snyderman R, Mergenhagen SE 1976 Chemotaxis of macrophages. In: Nelson DS (ed) Imunobiology of the Macrophage. Academic Press, New York, pp 323-348

27. Wilkinson PC, Allan RB 1980 The locomotor behaviour of human blood monocytes in chemotactic and chemokinetic environments and the role of substratum in monocyte locomotion. In: Van Furth R (ed) Mononuclear Phagocytes: Functional Aspects Part I. Martinus Nijhoff, The Hague, pp 475-500

28. Parrott DMV, Wilkinson PC 1981 Lymphocyte locomotion and migration. Prog Allergy 28:193-284

29. Demarest GB, Hudson LD, Altman LC 1979 Impaired alveolar macrophage chemotaxis in patients with acute smoke inhalation. Am Rev Respir Dis 119:279-286

30. Khan AJ, Rosenfeld W, Vadapalli M, Biagton J, Khan P, Huq A, Evans HE 1980 Chemotaxis and random migration of human milk cells. J Pediatr 96:879-882 